\title{
CONSUMER TRUST AND COGNITIVE DISSONANCE TOWARDS ONLINE REVIEWS IN SELECTED RESORTS: A PREFERENTIAL MODEL
}

\author{
Maria Corazon A. Buena ${ }^{1}$ \\ PhD Student, University of Santo Tomas, Philippines. \\ Assistant Professor II, Cavite State University, Philippines. \\ (Email: cora_a_buena@yahoo.com.ph) \\ Eduardo G. Ong, Ph.D. ${ }^{2}$ \\ Professor, University of Santo Tomas, Philippines. \\ (Email: dregong2010@yahoo.com)
}

Received date: $28-11-2019$

Revised date: 04-12-2019

Accepted date: 06-12-2019

Published date: 10-12-2019

To cite this document: Buena, M. C. A., \& Ong, E. G. (2019). Consumer Trust and Cognitive Dissonance Towards Online Reviews in Selected Resorts: A Preferential Model. Journal of Information System and Technology Management, 4(15), 27-40.

DOI: $10.35631 /$ jistm. 415003

\begin{abstract}
The increasing trends of using online consumer reviews as bases before the actual purchase of a product or service are now substantial in the consumer decision-making process. Consumers nowadays want not only the core products or services, but other offerings as well, and they usually verify these with the online reviews. The resort industry is not exempted from these deviations. This study particularly investigated the determinants of consumer trust in online reviews, the assertions of cognitive dissonance as part of pre-purchase behavior, and their effects on customers' purchase likelihood. The study sites were selected resorts in Region $I V$ in the Philippines, while the perspective of 500 customers located in the Philippines specifically in Metro Manila, Metro Davao and Metro Cebu were utilized. Initial findings showed that argument quality (.785), source credibility (.812) and perceived quantity of reviews (.785) had greatly influence consumer trust. However, the assertions of pre-purchase cognitive dissonance were not influenced by the determinants. Moreover, results revealed that pre-purchase cognitive dissonance (with a value of -0.084) has a negative impact on the purchase likelihood whereas consumers' trust (with a value of 0.522) has a positive impact on the purchase likelihood.
\end{abstract}

Keywords: Consumer Trust, Cognitive Dissonance, Online Reviews, Resorts

\section{Introduction}

The resort industry is composed of lodging and recreational establishments that provide both facilities on the same premises. Resorts are viewed as places for relaxation as well as recreation, and as such the resort segment of the industry typically offers guests a broad spectrum of 
amenities and various services, that may include but are not limited to: entertainment (such as gambling venues), swimming pools, health centers, valet parking, food and beverage services, and conference and convention facilities (Resorts Market Research Reports \& Industry Analysis, 2019).

The resort industry in the Philippines, has contributed to the economic growth of the country. According to the Department of Tourism, the increase in tourist arrivals during the months of January to April of 2012, was due to the contribution of the resort industry that offers good facilities, products and services both to foreign and local market (Raquel, 2012; EnriquezMagkasi \& Caballero, 2014). These good attributes of a resort can sometimes be authenticated through reading online consumer reviews, hence may signify some effects on purchase likelihood of consumers.

The third most reliable source that consumers looked up about a product while in a shop is the online reviews (49\%). This is based on Global Online Consumer Report (2017) which further stated that other information such as price comparison with other retailers $(65 \%)$, product information/specifications (61\%), product options - e.g. color, size, style, etc. (35\%) and store inventory/availability $(16 \%)$ are the other information that consumers looked up about a product while in a shop. Beyond quality, authenticity and security, trust affects consumers' attitudes toward technology, specifically online consumer reviews. In addition, reviews influence a customer's trust in the product/service and/or vendor/service provider (Yang, 2013), and further influence also the formation of cognitive dissonance.

Knowledge about products the consumers want to buy usually came from the online reviews as buyers use these as source. The information confined in the reviews reflects personal experiences of the reviewer. These experiences may provide two important considerations: deliver consumers with additional information not declared in the official product description; and/or allow them to validate that the information advertised by the manufacturer is precise. The information in product reviews can be used to overcome the problem of information irregularity, that is aggravated in online sales environment, that states that sellers possess more product information than buyers (Ong, 2013).

While there are studies that have indicated consumers' trust in online consumer reviews, minimal research has studied on consumer trust and pre-purchase cognitive dissonance particularly in the resort industry. Currently, there is a knowledge gap in the literature on a comprehensive study on consumer trust and pre-purchase cognitive dissonance towards online consumer reviews in resorts since related research studies are almost non-existent. The trust acquired in using online reviews as compared to actual use and purchase of resort services and amenities are surely influenced by different factors. Hence, the focus of this study.

\section{Scope and Limitations of the Study}

The purpose of this study is to investigate the determinants of online consumer reviews on the combined analysis of consumer trust and cognitive dissonance in the pre-purchase behavior of consumers. Hence, the study focused on describing the four important elements of this study: online consumer reviews in resorts, consumer trust, pre-purchase cognitive dissonance and purchase likelihood. The research design was a mixed method approach combining both quantitative and qualitative methodologies using online survey research technique and interviews. The participants of this study were 500 actual and prospective resort customers and 25 resort managers/employees. The conceptual framework of the study was profoundly based on Uncertainty Reduction Theory (URT) and Cognitive Dissonance Theory-Action-based- 
Model of CDT. This study aims to develop a model based on the effects of consumer trust and cognitive dissonance to purchase likelihood of customers after evaluating online consumer reviews.

The study areas covered five selected resorts in Region IV with the following qualifiers: a) has more than 100 online consumer reviews; and b) number one in ranking in their respective location/provinces. The resorts belong to the Ten Best Philippines Beach Resorts categorized and ranked by travelers as of March 2019. These are Out of the Blue Resort in Puerto Galera (386 OCR); Acuatico Beach Resort and Hotel in Laiya, Batangas (524 OCR); Villa Escudero Resort in San Pablo City, Laguna (313 OCR); Tanza Oasis Hotel and Resort in Tanza, Cavite (130 OCR); and Club Balai Isabel in Talisay, Batangas (710 OCR). The mentioned resorts ranked as number 1 in their respective location/provinces. The selection is due to what is specified in the article "Tourist Accommodation Facilities (Hotel/Resort)" which stated that Region IV is categorized as potential sites for new hotels and resorts. This is further supported by enabling laws/policies which includes the Tourism Act of 2009 (R.A. 9593) which was enacted on 12 May 2009. The said law declares "a national policy for tourism as an engine of investment, employment, growth and national development, and strengthens the Department of Tourism (DOT) and its attached agencies to effectively and efficiently implement the said policy."

Because there are reviews, specifically, conducted by Soutor \& Sweeney (2013) led the people to believe that consumers are bound to encounter dissonance in light of the fact that in the present time of consumer empowerment, clients, especially the more youthful ones, have greater inclusion and higher desires of services. The rise of Internet commerce is another reason leading to increase in cognitive dissonance, hence this study focused on the determinants of consumer trust towards online reviews, their effects to cognitive dissonance and further, the impact to purchase likelihood.

\section{Research Problem}

This study explored the perspectives of customers on the determinants of consumer trust and the assertions of pre-purchase cognitive dissonance towards online reviews and their impact to purchase likelihood, in selected resorts in the Philippines. The study tested the relationships between online consumer reviews (OCR) as independent variable, with its mediating variables: consumer trust (CT) as affected by argument quality (AQ), source credibility (SC) and perceived quantity of reviews $(\mathrm{PQR})$ and cognitive dissonance $(\mathrm{CD})$ as asserted by change belief (CB), change action (CA) and change action perception (CAP) and purchase likelihood (PL) as the dependent variable. The findings of this study can be valuable to resort industry and resort owners/managers to plan and effectively deliver their services using the best possible strategies.

\section{Related Literature}

\section{Determinants of Consumer Trust}

Several researches show that online trust is a key driver for the success of e-commerce (Hong and Cho, 2011; Macik and Macik, 2016), and consumer trust is believed to have essential role in successful operation of online retailer (Kim and Park 2013). In the online setting, it was asserted that consumers build trust in a Website by interfacing with the webpage, equivalent to how trust is shaped disconnected by means of interaction with a physical store. They additionally suggested that the fluctuation among on the web and disconnected trust incorporates buyer saw acceptability of Web website data, the apparent capability of the 
webpage to perform anticipated capacities and the apparent certainty of the website to work. With this, trust is observed to be a noteworthy driver to diminish any related hazard that might be experienced by customers.

In online communities, trust might be built through the sharing of knowledge and experience (Hajli \& Khani 2013; Zhao \& Lavin 2012). These two play an important role in building trust and are evidenced in several studies. Hajli and Khani (2013), furthermore, find that the level of trust for new products is augmented by social word of mouth. Moreover, online WOM quality is an antecedence of e-commerce trust, while Chen (2011) correspondingly finds that loyalty is greatly influenced by electronic word of mouth. On the other hand, Lee et al. (2011) discourse that trusted source is very important since trust could be transferred to an unknown target from a trusted target if the former is considered to be associated with a trusted source. Accordingly, OCRs might possibly figure trust in the e-vendor, for the reason that they are posted by a related experienced party, and also because they are usually alleged to be credible and trustworthy. Moreover, the social presence of a website, is found to have a positive correlation with consumer trust (Choi et al. 2011).

\section{Source Credibility}

Source credibility assigns one's impression of a correspondence source's aptitude and reliability (Bartikowski and Walsh, 2014). This is on the grounds that more prominent influence may result as of correspondence when the source of the message is seen as believable. Hence, source credibility in the research covers the believability of data recovered from a purchaser feeling stage, may represent change in brand expectations.

The believability of eWOM as purchaser item surveys may rely upon both, the wellspring of data (customer versus advertiser created audit locales) and the kind of item (experience versus seek items). This is due to the influence of online reviews that has frequently been accredited to their source credibility (Willemsen, Neijens \& Bronner, 2012). Product appraisals produced by reviewers who have analogous attitudes and demographic characteristics as the recipients of the reviews have a higher level of source trustworthiness than those with low similarity.

Based on a survey conducted by eMarketer, $70 \%$ of respondents considered "people like myself" to be trustworthy for product recommendations, and $64 \%$ are likely to purchase products recommended by “people like myself” (2010). Some online retailers have created fullfledged reviewers' profiles, so that readers may gain a better understanding of who wrote the reviews. Some creates detailed profiles for their reviewers and allows them to disclose important information. These profiles allow readers to filter undesired messages and match the most useful product information.

When the messenger reveals his personal information such as geographical information or gender, the credibility of message is increased (Jamil and Hasnu, 2013). In the online setting where there is absence of physical interface the impact becomes more rampant. In addition, the nonappearance of social cues tends to increase dependence on these identity disclosure cues to reduce uncertainty (Jamil and Hasnu, 2013). While studying reviews, Owusu et al. (2016) stated that the influence of source credibility associated with online consumer reviewers on brand attitude and purchase intention was also comparable to that of perceived source credibility associated with offline product reviewers.

The impact of reviewer characteristics has been largely unnoticed. Reviewer source credibility moderated the effects of the persuasiveness and completeness of product recommendations on 
perceived recommendation credibility, via an online consumer discussion forum (Luo et al., 2013). However, the contribution of source attributes remains unclear (Willemsen, Neijens \& Bronner, 2012), although several scholars have made mention of the possible influence (Hu \& Sundar, 2010).

Other researches related to product reviews validates that there is a positive correlation among source credibility and perceived helpfulness of online product reviews (Musambi \& Schuff, 2010; Willemsen et al., 2011), persuasiveness of online product reviews and consumers' trust in online product reviews.

The impact of the reviewer on the consumers can be described on other aspects such as reviewer identity. Research on the effects of online consumer reviews confirms that perceived source credibility of online consumer reviewers significantly influenced other consumers' purchase intentions (Al-Debei et al., 2015; Ayeh et al., 2013; Filieri, 2015). For instance, perceived reviewer credibility positively impacted perceived eWOM review credibility in an online discussion forum, which in turn directly enhanced product-purchase intentions (Chih et al., 2013). Likewise, reviewer source credibility moderated the effects of the persuasiveness and completeness of product recommendations on perceived recommendation credibility, via an online consumer discussion forum (Luo et al., 2013).

\section{Argument Quality}

It is valuable for a buyer directing on the web inquire about, that the suppositions posted are honest and present a dependable image of the marketplace. In the event that the open reviews are for reasons unknown skewed towards one end of the scale, the purchaser might be actuated to buy an item that does not portray the perfect decision. This phenomenon is often called review bias (Moen, Havro and Bjering, 2017).

The content of OCRs was commonly the focus of more recent OCR literature that examines perceived helpfulness. Cao, Duan, and Gan (2011) and Kuan et al. (2011) determined that the existence of both objective and subjective content influences helpfulness observations. However, Schlosser (2011) found that the relationship between including one- versus twosided arguments (i.e. pros and cons) in OCRs and consumers' perceived helpfulness is toneddown by the reviewer's product rating. He further stated that when a rating of the reviewer was extreme, two-sided OCRs were not perceived as supplementary helpful than one-sided OCRs. Notably, Yin, Bond, and Zhang (2014) suggested that researchers should encompass the examination of simple valence to differentiate more specific emotions. Specific emotions in reviews such as anxious and anger reviews were given emphasis. They verified that on edge reviews are seen as more supportive than incensed reviews since readers recognize that restless reviewers have given increasingly cautious thought to the substance. Moreover, these authors considered seller reviews, which are generally anonymous, as opposed to product reviews, which are often recognizable in terms of expertise and demographics.

As per review content, in general, research shows that negative reviews have more influence on consumer attitudes and behavior than positive reviews. The findings of Sandes and Urdan (2013) indicate that exposure to negative comments posted by consumers on the Internet about a brand, degrade the perceived brand image and reduce the purchase intention.

However, review quality is defined as the quality of a review's content from the perspective of information characteristics, including relevance, understandability, sufficiency, and objectivity (Chen \& Tseng, 2011; Wu, 2013). Shan (2014) mentioned in his study that it is relatively more 
persuasive than a comment that expresses feelings or a recommendation without specific reasons if a review contains more understandable and objective comments with sufficient reasons given for the recommendation. He further stated that review quality has a positive effect on purchase intention. He even added that prior studies suggest that messages that are understandable and objective are more effective than messages that are emotional and subjective. Another study proposed that the presence of consumer reviews with a counterargument were more effective than reviews expressing one-sided attitudes as cited by Shan (2014).

\section{Perceived Quantity of Reviews}

Many studies have verified the substantial influence of product rating on a consumer's purchasing decision (Hu et al. 2016; Kolomiiets et al. 2016). Numeric product evaluations can indicate how much consumers prefer products but cannot deliver enough information on the reasons for products' success or failure. In disparity, text reviews can provide more visions into such a why question because text reviews can disclose consumers' deep thoughts and comprehensive experiences (Tsang and Prendergast, 2009).

Further, Nan, Yang and Dou (2017), stated that the word-of-mouth effect is a key factor in prompting consumers' purchasing decision, which is seven times larger than that of an emagazine and two times than that of an advertisement. An increase in the number of reviews connotates a more obvious information overload problem. This problem has prohibited potential consumers from completely exploiting the reviews; that means, it is impossible for consumers to read all the reviews. In order to improve the consumers' purchasing proficiency, online review systems offer a voting mechanism for consumers to prompt their attitude for a review, and then the website displays these reviews based on the quantity of supportive votes. Because of this, certain studies attempt to address such issues. Different features were considered to justify the points of evaluating the reviews. It is noted that Martin \& $\mathrm{Pu}(2014)$ recommend a helpful votes' model to select reviews containing valuable information from the viewpoint of meta-data, semantic and emotion. This research conducts empirical studies to support their models and, to some degree, unravel these issues.

Review quantity mentions the number of reviews regarding a specific product or service. It is appealed that an expansion in the quantity of surveys substantially affects deals development (Ghose \& Ipeirotis, 2010; F. Zhu \& Zhang, 2010). For instance, when there are ten reviews or less, consumers tend to read all the reviews. However, the results show when more reviews are available, consumers spend less time reading each review (Ong, 2013). Further, when the volume of reviews is low, say 10 reviews, to achieve enough information about the product, customers are assumed to have to intricate on the content of reviews. However, if the number of reviews is high, say 100, most customers are assumed to simply make a verdict based more on the statistical evidence than on the narrative evidence (Yang, 2013).

In addition, Shan (2014), stated that customers are influenced by the amount of eWOM as opposed to the nature of reviews, but only when their product involvement level is low.

\section{Methodology}

This research used quantitative research design to attain the objectives of the study. This study used the Uncertainty Reduction Theory (URT) and Cognitive Dissonance Theory (CDT) as the theoretical bases which were evaluated using a sequence of quantitative data and analysis in order to produce a final model that best expounds the prime phenomena of the data that were collected. 
A survey questionnaire, which was subjected for validity and reliability tests, was used to gather the data from 500 current or prospective customers of resorts. The data were collected through online survey with the internet users. Google forms was the online survey builder which was utilized in the study. The responses were collected by conveying the link/form to the existing connections through emails, Viber, Messenger and Instagram.

\section{Results and Discussion}

Table 1 shows the customer profile of the respondents from which the data in this study were obtained. Overall, the sample was identified as either male or female, individuals between 21 to 30 years old with college degree.

A relatively close gender distribution of customers participated in the surveys, with females slightly higher $(n=265,53 \%)$ than males $(n=235,47 \%)$. The age distribution showed that most of the respondents belonged to the age groups of 21 to 30 years old $(n=192,38.4 \%)$ and 31 to 40 years $(n=172,34.4 \%)$, respectively. Only few respondents belonged to $41-50$ age group $(n=67,13.4 \%)$ and 51 and older age group $(n=49,9.8 \%)$, while the lowest number belonged to 20 years and below with 20 respondents (4\%). Majority of the respondents were college graduates or with bachelor's degree $(n=308,61.6 \%)$. Other respondents completed post-graduate degree $(\mathrm{n}=77,15.4 \%)$, high school or below $(\mathrm{n}=72,14.4 \%)$, and had diploma education $(n=43,8.6 \%)$, respectively. More than half of the respondents are salaried $(n=299$; $59.8 \%)$. Other respondents were home maker $(\mathrm{n}=92 ; 18.4 \%)$, self-employed $(\mathrm{n}=60,12 \%)$, student $(\mathrm{n}=33,6.6 \%)$, retired $(\mathrm{n}=12,2.4 \%)$ and others $(\mathrm{n}=4,0.8 \%)$. Data indicate that a typical resort customer reading online reviews could either be female or male, between 21 to 30 years of age with a college degree and salaried.

Table 1: Profile of the Customer Respondents

\begin{tabular}{|c|c|c|}
\hline Profile & $\begin{array}{c}\text { Frequency } \\
(n=500)\end{array}$ & Percent \\
\hline \multicolumn{3}{|l|}{ Gender } \\
\hline Female & 265 & 53 \\
\hline Male & 235 & 47 \\
\hline TOTAL & 500 & 100 \\
\hline \multicolumn{3}{|l|}{ Age } \\
\hline 20 and Below & 20 & 4 \\
\hline $21-30$ years old & 192 & 38.4 \\
\hline $31-40$ years old & 172 & 34.4 \\
\hline $41-50$ years old & 67 & 13.4 \\
\hline 51 and older & 49 & 9.8 \\
\hline TOTAL & 500 & 100 \\
\hline \multicolumn{3}{|l|}{ Educational Attainment } \\
\hline High school or below & 72 & 14.4 \\
\hline Diploma & 43 & 8.6 \\
\hline College/ Bachelor's Degree & 308 & 61.6 \\
\hline Post-graduate Degree & 77 & 15.4 \\
\hline TOTAL & 500 & 100 \\
\hline \multicolumn{3}{|l|}{ Occupation } \\
\hline Salaried & 299 & 59.8 \\
\hline
\end{tabular}




\begin{tabular}{lcc} 
Self-Employed & 60 & 12 \\
Home Maker & 92 & 18.4 \\
Retired & 12 & 2.4 \\
Student & 33 & 6.6 \\
Others & 4 & 0.8 \\
TOTAL & $\mathbf{5 0 0}$ & $\mathbf{1 0 0}$ \\
\hline
\end{tabular}

The consumer trust of the respondents towards online reviews was measured using three determinants, namely: argument quality, source credibility and perceived quantity of reviews as summarized in Table 2. The table also figured out the three assertions of cognitive dissonance, namely: change in belief, change in action and change in action perception.

Most of the respondents rated their agreement as high towards the three determinants of consumer trust (AQ - $\mathrm{n}=362,72.4 \%$; $\mathrm{SC}-\mathrm{n}=338,67.6 \%$; $\mathrm{PQR}-\mathrm{n}=333,66.6 \%)$. However, there is zero respondent who signified a very low agreement towards the three determinants of consumer trust. The remaining respondents agreed towards argument quality as moderate $(\mathrm{n}=$ $80,16 \%)$, very high $(\mathrm{n}=45,9 \%)$, fair $(\mathrm{n}=10,2 \%)$ and low $(\mathrm{n}=3,0.6 \%)$. In terms of source credibility, other respondents considered a moderate $(n=114,22.8 \%)$, very high $(n=35,7 \%)$, fair $(\mathrm{n}=8,1.6 \%)$, and low $(\mathrm{n}=5,1 \%)$ agreement. Furthermore, in terms of perceived quantity of reviews, other respondents rated their agreement as moderate $(\mathrm{n}=83,16.6 \%)$, very high $(\mathrm{n}=$ $69,13.8 \%)$, fair $(n=11,2.2 \%)$ and low $(n=4,0.8 \%)$.

On the other hand, majority of the respondents rated themselves as they have agreed low in terms of the assertions of cognitive dissonance $(\mathrm{CB}-\mathrm{n}=156,31.2 \%$; $\mathrm{CA}-\mathrm{n}=160,32 \%$; CAP $-\mathrm{n}=164,32.8 \%)$. Only few of them implied that they have a very low agreement towards the three assertions of cognitive dissonance $(\mathrm{CB}-\mathrm{n}=4,0.8 \%$; $\mathrm{CA}-\mathrm{n}=5,1 \%$; CAP $-\mathrm{n}=3$, $0.6 \%)$. However, the rest of the respondents indicated different ratings towards change in belief, such as fair $(\mathrm{n}=111,22.2 \%)$, high $(\mathrm{n}=107,21.4 \%)$, moderate $(\mathrm{n}=91,18.2 \%)$ and very high $(\mathrm{n}=31,6.2 \%)$. Moreover, the ratings given by the respondents to change in action were as follows: fair $(\mathrm{n}=114,22.8 \%)$; high $(\mathrm{n}=110,22 \%)$; moderate $(\mathrm{n}=75,15 \%)$; and very high $(\mathrm{n}=36,7.2 \%)$. As regards to the respondents' ratings in change in action perception, the following were revealed: high $(n=132,26.4 \%)$; fair $(n=89,17.8 \%)$; moderate $(n=84,16.8 \%)$; and very high $(\mathrm{n}=28,5.6 \%)$.

This profile suggests that the sample of the study brings individuals who are prepared for the use of online reviews as bases for purchase and avail of services. This also allows to conclude that this group is accustomed to development of trust towards online reviews and counter prepurchase cognitive dissonance.

Table 2: Determinants of Consumer Trust and Assertions of Cognitive Dissonance Towards Online Reviews

\begin{tabular}{lcc}
\hline \multicolumn{1}{c}{ Indicator } & $\begin{array}{c}\text { Frequency } \\
(\mathbf{n = 5 0 0 )}\end{array}$ & Percent \\
\hline Argument Quality & & \\
Very Low & 0 & 0 \\
Low & 3 & 0.6 \\
Fair & 10 & 2 \\
Moderate & 80 & 16 \\
High & 362 & 72.4 \\
\hline
\end{tabular}




\begin{tabular}{|c|c|c|}
\hline Very High & 45 & 9 \\
\hline TOTAL & 500 & 100 \\
\hline \multicolumn{3}{|c|}{ Source Credibility } \\
\hline Very Low & 0 & 0 \\
\hline Low & 5 & 1 \\
\hline Fair & 8 & 1.6 \\
\hline Moderate & 114 & 22.8 \\
\hline High & 338 & 67.6 \\
\hline Very High & 35 & 7 \\
\hline TOTAL & 500 & 100 \\
\hline \multicolumn{3}{|c|}{ Perceived Quantity of Reviews } \\
\hline Very Low & 0 & 0 \\
\hline Low & 4 & 0.8 \\
\hline Fair & 11 & 2.2 \\
\hline Moderate & 83 & 16.6 \\
\hline High & 333 & 66.6 \\
\hline Very High & 69 & 13.8 \\
\hline TOTAL & 500 & 100 \\
\hline \multicolumn{3}{|l|}{ Change in Belief } \\
\hline Very Low & 4 & 0.8 \\
\hline Low & 156 & 31.2 \\
\hline Fair & 111 & 22.2 \\
\hline Moderate & 91 & 18.2 \\
\hline High & 107 & 21.4 \\
\hline Very High & 31 & 6.2 \\
\hline TOTAL & 500 & 100 \\
\hline \multicolumn{3}{|l|}{ Change in Action } \\
\hline Very Low & 5 & 1 \\
\hline Low & 160 & 32 \\
\hline Fair & 114 & 22.8 \\
\hline Moderate & 75 & 15 \\
\hline High & 110 & 22 \\
\hline Very High & 36 & 7.2 \\
\hline TOTAL & 500 & 100 \\
\hline \multicolumn{3}{|c|}{ Change in Action Perception } \\
\hline Very Low & 3 & 0.6 \\
\hline Low & 164 & 32.8 \\
\hline Fair & 89 & 17.8 \\
\hline Moderate & 84 & 16.8 \\
\hline High & 132 & 26.4 \\
\hline Very High & 28 & 5.6 \\
\hline TOTAL & 500 & 100 \\
\hline
\end{tabular}

Table 3 shows the determinants of online reviews in resorts and the degree of their effects to the consumers' trust towards online reviews in resorts. Spearman rank correlation coefficient was the statistical test used to determine if there is a significant relationship between source credibility (SC) and consumers' trust (CT), argument quality (AQ) and consumers' trust (CT) and perceived quantity of reviews $(\mathrm{PQR})$ and consumers' trust $(\mathrm{CT})$. The results revealed that the determinants $(\mathrm{SC}=0.812, \mathrm{AQ}=0.785, \mathrm{PQR}=0.785)$ greatly affects consumers' trust with 
a p-value equal to 0.00 , which is less than the designated level of significance of 0.05 . These results signify that there is a linear relationship or a direct relationship among the variables, wherein the higher the perceptions of the respondents on SC, AQ and PQR, the higher the consumers' trust towards online reviews in resorts.

However, the results led to the rejection of the following hypotheses: $H_{o} 1$ : Argument quality does not affect the consumers' trust towards online reviews in resorts; $H_{o} 2$ : Source credibility does not affect the consumers' trust towards online reviews in resorts; $H_{o} 3$ : Perceived quantity of reviews does not affect the consumers' trust towards online reviews in resorts.

Table 3: Relationship Among the Determinants of Online Reviews in Resorts and Consumers' Trust

\begin{tabular}{lcrlc}
\hline \multicolumn{1}{c}{ Determinant } & Value & $\begin{array}{c}\text { P- } \\
\text { value }\end{array}$ & \multicolumn{1}{c}{ Interpretation } & Remarks \\
\hline Source Credibility & 0.812 & $0.000^{*}$ & $\begin{array}{l}\text { Source Credibility affects consumers' } \\
\text { trust towards online reviews in resorts }\end{array}$ & Reject Ho \\
Argument Quality & 0.785 & $0.000^{*}$ & $\begin{array}{l}\text { Argument Quality affects consumers' } \\
\text { trust towards online reviews in resorts }\end{array}$ & Reject Ho \\
$\begin{array}{l}\text { Perceived Quantity } \\
\text { of Reviews }\end{array}$ & 0.785 & $0.000^{*}$ & $\begin{array}{l}\text { Perceived Quantity of Reviews affects } \\
\text { consumers' trust towards online reviews } \\
\text { in resorts }\end{array}$ & Reject Ho \\
\hline$*_{\text {p-value is less than } 0.05 \text { level of significance }}$ & & &
\end{tabular}

The informational and social components of online reviews, namely the argument quality and source credibility, respectively, were tested to ascertain if they influence the three assertions of Action-based model of Cognitive Dissonance Theory (CDT) such as a) change belief (CB); b) change action (CA); and c) change action perception (CAP). Spearman rank correlation coefficient was used to measure the degree of association to identify the values if there are relationships among the variables. Table 4 exposed that the determinants and assertions ( AQ and $\mathrm{CB}=0.974, \mathrm{AQ}$ and $\mathrm{CA}=0.782, \mathrm{AQ}$ and $\mathrm{CAP}=0.408, \mathrm{SC}$ and $\mathrm{CB}=0.176, \mathrm{SC}$ and $\mathrm{CA}$ $=0.189, \mathrm{SC}$ and $\mathrm{CAP}=0.025)$ with $\mathrm{p}$-values greater than 0.05 level of significance indicate that one variable does not influence the other.

The results led to the acceptance of the following hypotheses: $H_{o} 4$ : The informational (argument quality) components of online reviews in resorts will not influence the three assertions of cognitive dissonance: change belief, change action and change action perception; $H_{o} 5$ : The social (social credibility) components of online reviews in resorts will not influence the three assertions of cognitive dissonance: change belief, change action and change action perception. However, the results indicated that it was only the change action perception led to the rejection of the hypothesis, since source credibility influences change action perception. 
Table 4: Relationship of the Determinants of Online Reviews and the Assertions of Cognitive Dissonance

\begin{tabular}{|c|c|c|c|c|}
\hline Determinant/Assertion & Value & P-value & Interpretation & Remarks \\
\hline $\begin{array}{l}\text { Argument Quality and } \\
\text { Change Belief }\end{array}$ & 0.001 & $0.974^{*}$ & $\begin{array}{l}\text { Argument } \\
\text { Quality does not } \\
\text { influence Change } \\
\text { Belief }\end{array}$ & Accept Ho \\
\hline $\begin{array}{l}\text { Argument Quality and } \\
\text { Change Action }\end{array}$ & -0.012 & $0.782 *$ & $\begin{array}{l}\text { Argument } \\
\text { Quality does not } \\
\text { influence Change } \\
\text { Action }\end{array}$ & Accept Ho \\
\hline $\begin{array}{lr}\text { Argument } & \text { Quality and } \\
\text { Change } & \text { Action } \\
\text { Perception } & \end{array}$ & -0.037 & $0.408 *$ & $\begin{array}{l}\text { Argument } \\
\text { Quality does not } \\
\text { influence Change } \\
\text { Action Perception }\end{array}$ & Accept Ho \\
\hline $\begin{array}{l}\text { Source Credibility and } \\
\text { Change Belief }\end{array}$ & -0.061 & $0.176^{*}$ & $\begin{array}{l}\text { Source } \\
\text { Credibility does } \\
\text { not influence } \\
\text { Change Belief }\end{array}$ & Accept Ho \\
\hline $\begin{array}{l}\text { Source Credibility and } \\
\text { Change Action }\end{array}$ & -0.059 & $0.189^{*}$ & $\begin{array}{l}\text { Source } \\
\text { Credibility does } \\
\text { not influence } \\
\text { Change Action }\end{array}$ & Accept Ho \\
\hline $\begin{array}{l}\text { Source Credibility and } \\
\text { Change } \quad \text { Action } \\
\text { Perception }\end{array}$ & -0.100 & $0.025^{*}$ & $\begin{array}{l}\text { Source } \\
\text { Credibility } \\
\text { influences } \\
\text { Change Action } \\
\text { Perception }\end{array}$ & Reject Ho \\
\hline
\end{tabular}

The impact of cognitive dissonance and consumers' trust to purchase likelihood as shown in table 5 was tested using regression analysis at $5 \%$ level of significance. The results revealed that cognitive dissonance (with a value of -0.084) has a negative impact to the purchase likelihood, whereas consumers' trust (with a value of 0.522) has a positive impact to the purchase likelihood. Therefore, the model:

$$
\begin{gathered}
P L=B o+\left(B_{1} x \text { Cognitive Dissonance }\right)+\left(B_{2} x \text { Consumer Trust }\right) \\
=2.608-0.084(C D)+0.522(C T)
\end{gathered}
$$

was engendered to additionally explain how purchase likelihood was affected by cognitive dissonance and consumer trust.

However, the results directed to the rejection of the hypothesis: $H_{o} 6$ : Consumer trust and cognitive dissonance do not affect the purchase likelihood of consumers, and that there is no significant relationship between the increase or decrease of the variables. 
Table 5: Impact of Cognitive Dissonance and Consumer Trust to Purchase Likelihood

\begin{tabular}{lllllll}
\hline Variables & \multicolumn{1}{c}{$\begin{array}{c}\text { Beta } \\
\text { coefficients }\end{array}$} & $\begin{array}{c}\text { Standard } \\
\text { Error }\end{array}$ & t-value & P-value & Interpretation & Remarks \\
\hline Constant & 2.608 & 0.230 & 11.324 & $0.000^{*}$ & Significant & Reject Ho \\
Dissonance & -0.084 & 0.020 & -4.289 & $0.000^{*}$ & Significant & \\
Customers' & 0.522 & 0.046 & 11.404 & $0.000^{*}$ & Significant & \\
Trust & & & & & & \\
*p-value is greater than 0.05 level of significance & & & & \\
\hline
\end{tabular}

\section{Conclusion}

The following conclusions were drawn based on the results of the study:

The determinants of consumer trust towards online reviews of resorts among customers were argument quality, source credibility and perceived quantity of reviews. However, the assertions of pre-purchase cognitive dissonance towards online reviews in resorts were change belief, change action and change action perception.

Based on the standardized beta coefficients, consumers' trust (0.522) towards online reviews had positive impact to the purchase likelihood of customers, whereas cognitive dissonance (0.084) towards online reviews had negative impact to the purchase likelihood of customers.

It is irrefutable that argument quality, source credibility and perceived quantity of reviews influence the consumers' trust towards online reviews in resorts.

The informational and social components of online reviews do not influence the assertions of cogntive dissonance, namely change in belief and change in action. Meanwhile, only change in action perception was influenced by the two components of online reviews.

\section{References}

Al-Debei, M., Akroush, M.N. and Ashouri, M.I. (2015), "Consumer attitudes towards online shopping", Internet Research, Vol. 25 No. 5, pp. 707-733.

Ayeh, J.K., Au, N. and Law, R. (2013), "Do we believe in TripAdvisor? Examining credibility perceptions and online travelers' attitude toward using user-generated content", Journal of Travel Research, Vol. 52 No. 4, pp. 437-452.

Bartikowski, B., \& Walsh, G. (2014). Attitude contagion in consumer opinion platforms: Posters and lurkers. Electronic Markets, 24(3), 207-217. doi: http://dx.doi.org/10.1007/s12525-013-0149-z

Cao, Qing, Wenjing J. Duan, and Wiwei Gan (2011), "Exploring Determinants of Voting for the 'Helpfulness' of Online User Reviews: A Text Mining Approach," Decision Support Systems, 50 (2), 511-521.

Chen, S. (2011) "Understanding the effects of technology readiness, satisfaction and electronic wordof-mouth on loyalty in 3C products", Australian Journal of Business and Management Research Vol, vol. 1, no. 3.

Chen, C., \& Tseng, Y. (2011). Quality evaluation of product reviews using an information quality framework. Decision Support Systems, 50 (4), 755-768.

Chih, W.H., Wang, K.Y., Hsu, L.C. and Huang, S.C. (2013), "Investigating electronic wordof-mouth effects on online discussion forums: the role of perceived positive electronic word-of-mouth review credibility", Cyberpsychology, Behavior, and Social Networking, Vol. 16 No. 9, pp. 658-668. 
Choi, J., Lee, H.J. and Kim, Y.C. (2011) "The Influence of Social Presence on Customer Intention to Reuse Online Recommender Systems: The Roles of Personalization and Product Type", International Journal of Electronic Commerce, vol. 16, no. 1, pp. 129154.

Filieri, R. (2015), "What makes online reviews helpful? A diagnosticity-adoption framework to explain informational and normative influences in e-WOM", Journal of Business Research, Vol. 68 No. 6, pp. 1261-1270.

Hajli, M. and Khani, F. (2013) "Establishing Trust in Social Commerce through Social Word of Mouth", International Journal of Information Science and Management (IJISM), , pp. 39-53.

Hong, I. B., and H. Cho. 2011. 'The Impact of Consumer Trust on Attitudinal Loyalty and Purchase Intentions in b2c E-Marketplaces: Intermediary Trust vs. Seller Trust.' International Journal of Information Management 31(5):469-79.

Hu, Y., \& Sundar, S. S. (2010). Effects of online health sources on credibility and behavioral intentions. Communication Research, 37, 105-132.

Hu H.W, Y.L. Chen, and P.T. Hsu, "A Novel Approach to Rate and Summarize Online Reviews according to User Specified Aspects," Journal of Electronic Commerce Research, Vol. 17, No. 2:132-152, 2016.

Jamil, R. A., \& Hasnu, S. A. F. (2013). Consumer's reliance on word of mouse: Influence on consumer's decision in an online information asymmetry context. Journal of Business \& Economics, 5(2), 171-205. Retrieved from https://search.proquest.com/docview/1640762747? accountid=38643

Kim, S., and H. Park. 2013. 'Effects of Various Characteristics of Social Commerce (SCommerce) on Consumers' Trust and Trust Performance. 'International Journal of Information Management 33:318-32.

Kolomiiets A., N. Dens, and P. De Pelsmacker, "The Wrap Effect in Online Review Sets Revisited: How Perceived Usefulness Mediates the Effect on Intention Formation," Journal of Electronic Commerce Research, Vol. 17, No. 4:280-288, 2016.

Kuan, K. K. Y., Hui, K.-L., Prasarnphanich, P., and Lai, J. H. Y (2011), "Online Voting and Review Helpfulness: An Empirical Investigation,” (working paper).

Lee, J., Park, D. and Han, I. (2011) "Emerald Article: The different effects of online consumer reviews on consumers' purchase intentions depending on trust in online shopping malls: An advertising perspective", Internet research, vol. 21, no. 2, pp. 187-206.

Luo, C., Luo, X.R., Schatzberg, L. and Sia, C.L. (2013), "Impact of informational factors on online recommendation credibility: the moderating role of source credibility", Decision Support Systems, Vol. 56, December, pp. 1-524.

Macik, R., \& Macik, D. (2016). Trust and Product/Sellers reviews as factors influencing online product comparison sites usage by young consumers. Managing Global Transitions, 14(2), 195-215. Retrieved from https://search.proquest.com/docview/1889417285?accountid=38643

Martin L., and P. Pu, "Prediction of Helpful Reviews Using Emotions Extraction," Proceedings of the 28th AAAI Conference on Artificial Intelligence, pp. 1551-1557, Québec, July 2014.

Moen, Ø., Havro, L. J., \& Bjering, E. (2017). Online consumers reviews: Examining the moderating effects of product type and product popularity on the review impact on sales. Cogent Business \& Management, 4(1) doi: http://dx.doi.org/10.1080/23311975.2017.1368114

Mudambi, S. M., \& Schuff, D. (2010). What makes a helpful online review? A study of customer reviews on Amazon. com. MIS Quarterly, 34, 185-200. 
Nan, G., Yang, J., \& Dou, R. (2017). Do only review characteristics affect consumers' online behaviors? A study of relationship between reviews. Journal of Electronic Commerce Research, 18(4), 330-345. Retrieved from https://search.proquest.com/docview/1980697403? accountid=38643

Ong, T. C. (2013). Product reputation manipulation: The characteristics and impact of shill reviews (Order No. 3562656). Available from ABI/INFORM Global. (1399161414). Retrieved from https://search.proquest.com/docview/1399161414?accountid=38643

Owusu, R.A., Mutshinda, C.M., Antai, I., Dadzie, K.Q. and Winston, E.M. (2016), "Which UGC features drive web purchase intent? A spike-and-slab Bayesian variable selection approach", Internet Research, Vol. 26 No. 1, pp. 22-37.

Schlosser, Ann E. (2011), "Can Including Pros and Cons Increase the Helpfulness and Persuasiveness of Online Reviews? The Interactive Effects of Ratings and Arguments," Journal of Consumer Psychology, 21(3), 226-39.

Shan, Y. (2014). The credibility of online product reviews: Do perceived similarity, source prestige, and argument quality foster the emergence of trust? International Journal of Electronic Commerce, pp. 11-23

Tsang, A.S.L. and Prendergast, G. (2009), "Is a 'star' worth a thousand words?: the interplay betweenproduct-reviewtextsandratingvalences",EuropeanJournalofMarketing,Vol.43 Nos11/12,pp.1269-1280.

Willemsen, L. M., Neijens, P. C., \& Bronner, F. (2012). The ironic effect of source identification on the perceived credibility of online product reviewers. Journal of Computer-Mediated Communication, 18, 16-31.

Wu, P. (2013). In search of negativity bias: An empirical study of perceived helpfulness of online reviews. Psychology \& Marketing, 30 (11), 971-984

Yin, Dezhi, Samuel Bond, and Han Zhang (2014), “Anxious Or Angry? Effects of Discrete Emotions on the Perceived Helpfulness of Online Reviews," MIS Quarterly, 38 (2), 539-560.

Zhao, Y. and Lavin, M. (2012) "An Empirical Study of Knowledge Transfer in Working Relationships with Suppliers in New Product Development", International Journal of Innovation Management, vol. 16, no. 02. 